\title{
Cost effective ways to make walking safer for children and adolescents
}

\author{
Barbara Preston
}

One thing that makes road accidents particularly abhorrent is that so many young people are killed and injured. ${ }^{1}$ In England and Wales in 1992 a quarter of all deaths in the age group 10-14 years were due to road accidents and $57 \%$ of these were pedestrians.

As well as the suffering caused by the injuries inflicted, fear of accidents means that people go out less than they otherwise would. It is especially important that children be able to play outside in safety. The National Playing Fields Association report, Mean Streets, stresses the importance for children of safe play areas near their homes, ${ }^{2}$ and the Department of the Environment report, Children at Play, states that 'The child who has not had the opportunity to meet his fellows, take part in their games, or explore his environment is deprived and therefore at a disadvantage'. ${ }^{3}$ In areas where houses have no gardens, and there is no safe play space nearby, the children may well be, as Colin Ward puts it, 'kept under house arrest'. ${ }^{4}$ Children's freedom to go out alone, and play with their friends, has been severely restricted during the past 20 years. In 1971 , as Hillman et al have shown, ${ }^{5} 63 \%$ of primary schoolchildren were allowed out alone in their leisure time; in 1990 only $37 \%$ were allowed to go out alone. In order to decide which measures should be used to reduce the number of pedestrians killed and injured it is important to consider where the accidents occur, which groups are most vulnerable, what the children were doing at the time of the accident, and what safety measures have been shown to be useful in Great Britain and in other countries.

\section{Where the accidents happen}

Most pedestrian accidents occur in built up areas, and the very young are most likely to be injured on minor roads, very near home, especially in inner city areas. ${ }^{6-8}$ Figures for Manchester are shown in table 1.

Mrs B Preston, 52 Low Fold, Marple Bridge, Stockport, Cheshire SK6 5DU, UK.

\section{Vulnerable groups}

People in the Registrar General's social classes IV and V - semiskilled and unskilled manual workers - suffer higher death rates, from most causes, than those in social class I - professional people, ${ }^{910}$ but one of the highest social class gradients is seen in deaths due to pedestrian accidents. ${ }^{11}$ Figures for child pedestrian deaths are given in table $2 .{ }^{12}$

\section{What the children were doing at the time} of the accident

Some children are killed and injured when they cross the road, to shop, visit friends, etc, or on the journey to or from school. In 1993, in Great Britain 4691 pedestrians under 16 years of age were injured on the journey to or from school. ${ }^{13}$ For pedestrians aged 5-15 years, $30 \%$ of the casualties occurred on the school journey. But many young children are injured when they are 'playing out' and not purposefully crossing the road. ${ }^{14}$

\section{International comparisons}

The pedestrian death rates, per 100000 populations for young people aged 0-9 years and 10-14 years, for the 25 countries for which information is available, are shown in table $3 .{ }^{15}$ (Countries with fewer than 50 pedestrians, of all ages, killed were not included.)

\section{Safety measures}

If the need to travel could be reduced so that more journeys could be undertaken by cycling or on foot and fewer people travelled by car the roads would be safer, ${ }^{16}$ but this is a very long term target. The reduction of traffic speeds is most important in the short term.

Table 2 Standardised mortality ratio $(S M R){ }^{\star}$ for child pedestrians in 1979-80,1982-3, by the social class of head of household

\begin{tabular}{lc}
\hline Social class & SMR \\
\hline I. Professional occupations & 47 \\
II. Intermediate occupations & 54 \\
III. N. Non-manual skilled & 48 \\
III. N. Manual skilled & 90 \\
IV. Partly skilled & 115 \\
V. Unskilled & 208 \\
Unoccupied & 348 \\
\hline
\end{tabular}

*The SMR corrects for the differences in the number of children in the different social classes. If the death rates were the same it would, by definition be 100 for each class. A SMR of 50 would mean that there were half as many killed, and a SMR of 200 would mean that there were twice as many killed, as would be expected if the death rate was the same for all classes.
Table 1 Casualties to pedestrians of different ages occurring in various locations in Manchester in 1985 (personal communication from the City Engineer and Surveyor)

\begin{tabular}{llll}
\hline Age & Central Manchester & \multicolumn{2}{l}{ Outside the centre of Manchester $\left({ }^{\circ}{ }_{o}\right)$} \\
\cline { 3 - 4 }$($ years $)$ & $\left(o_{o}\right)$ & Classified roads & Unclassified roads \\
\hline $0-4$ & 8 & 33 & 59 \\
$5-9$ & - & 42 & 58 \\
$10-14$ & 6 & 63 & 26 \\
$15-19$ & 22 & 52 & 14 \\
$20-64$ & 31 & 55 & 18 \\
$65+$ & 11 & 71 & \\
\hline
\end{tabular}




\section{Traffic calming}

Many countries have introduced traffic calming measures and before and after studies confirm their success, as shown in table 4. Traffic calming is intended to reduce speed to about $20 \mathrm{mph}$ and this would reduce the number and severity of casualties to children crossing the road. However, much lower speeds are necessary in residential areas if children are to play outdoors in safety.

\section{The need to play in safety}

In many countries it is recognised that children need to play outdoors with their friends and that, in residential areas, this means that the streets must be made safe for children to play. However, the present attitude in Britain, fostered by the Department of Transport, is that young children should not be allowed out alone and should never play on the road or

Table 3 Child pedestrian death rates 100000 population for 25 countries. The rates are for 1992 except for those marked ${ }^{\star}$ which are for 1991

\begin{tabular}{|c|c|c|c|}
\hline Country & $0-9$ years & Country & $10-14$ years \\
\hline Norway & 0.5 & Norway & 0 \\
\hline Italy* & 0.8 & Switzerland & 0 \\
\hline Netherlands & 0.8 & Austria & 0.6 \\
\hline Sweden & 0.9 & Croatia & 0.6 \\
\hline Denmark & 1.0 & Denmark & $0 \cdot 7$ \\
\hline France & $1 \cdot 2$ & Netherlands & 0.7 \\
\hline Spain & $1 \cdot 2$ & Germany & $0 \cdot 8$ \\
\hline Switzerland & $1 \cdot 2$ & Sweden & $0 \cdot 8$ \\
\hline Germany & $1 \cdot 3$ & Italy ${ }^{\star}$ & 0.9 \\
\hline UK & $1 \cdot 3$ & Spain & 0.9 \\
\hline Finland & 1.6 & France & $1 \cdot 0$ \\
\hline Hungary & 1.6 & Greece* & $1 \cdot 1$ \\
\hline $\mathrm{USA}^{\star} \star$ & 1.6 & Lithuania & $1 \cdot 1$ \\
\hline Austria & $1 \cdot 7$ & Hungary & 1.2 \\
\hline Greece* & $1 \cdot 7$ & $\mathrm{USA}^{\star}$ & 1.5 \\
\hline Ireland & 1.9 & Bulgaria & 1.7 \\
\hline Belgium & $2 \cdot 1$ & Ireland & $1 \cdot 7$ \\
\hline Estonia & $2 \cdot 5$ & Finland & 1.9 \\
\hline Belarius & $3 \cdot 4$ & Belgium & $2 \cdot 1$ \\
\hline Turkey & $4 \cdot 7$ & UK & $2 \cdot 3$ \\
\hline Russian Federation & $5 \cdot 1$ & Belarius & $2 \cdot 7$ \\
\hline Bulgaria & $5 \cdot 2$ & Turkey & $2 \cdot 7$ \\
\hline Lithuania & 5.9 & Estonia & $2 \cdot 7$ \\
\hline Croatia & $6 \cdot 7$ & Belarius & $2 \cdot 7$ \\
\hline Portugal* & $7 \cdot 2$ & Portugal* & 4.9 \\
\hline
\end{tabular}

Table 4 Casualty reductions (for all road users) as a result of traffic calming

\begin{tabular}{|c|c|c|c|}
\hline Source & Place & Type of casualty & $\begin{array}{l}\text { Percentage } \\
\text { reductions }\end{array}$ \\
\hline $\begin{array}{l}\text { Pharoah and Russell }{ }^{17} \\
\text { Nielson and Rassin }\end{array}$ & $\begin{array}{l}\text { Denmark } \\
\text { Ostebro and Copenhagen } \\
600 \text { schemes } \\
\text { Odense, safe routes to } \\
\text { school }\end{array}$ & $\begin{array}{l}\text { All casualties } \\
\text { All casualties } \\
\text { All casualties }\end{array}$ & $\begin{array}{l}32 \\
45 \\
85\end{array}$ \\
\hline $\begin{array}{l}\text { Pharoah and Russell } \\
\text { Boyers }^{19}\end{array}$ & $\begin{array}{l}\text { Germany } \\
\text { Hamburg } \\
\text { Heidelburg } \\
\text { Buxtehude } \\
\text { Buxtehude } \\
\text { Nordrhein-Westfallen } \\
\text { Nordrhein-Westfallen } \\
\text { Berlin } \\
\text { Various areas } \\
\text { Various areas } \\
\text { Various areas } \\
\text { Various areas } \\
\text { Various areas } \\
\text { Charlottenberg }\end{array}$ & $\begin{array}{l}\text { All casualties } \\
\text { All casualties } \\
\text { All casualties } \\
\text { Severe injuries } \\
\text { All injury accidents } \\
\text { Serious injuries } \\
\text { All injury accidents } \\
\text { All injury accidents } \\
\text { All injury accidents } \\
\text { All injury accidents } \\
\text { All injury accidents } \\
\text { All injury accidents } \\
\text { Child injury accidents/ } \\
1000 \text { children }\end{array}$ & $\begin{array}{l}27 \\
44 \\
14 \\
62 \\
45 \\
53 \\
\\
41 \\
53 \\
70 \\
76 \\
83 \\
64\end{array}$ \\
\hline Pharoah and Russell ${ }^{17}$ & $\begin{array}{l}\text { The Netherlands } \\
\text { Eindhoven and Rijswijk }\end{array}$ & $\begin{array}{l}\text { All road users } \\
\text { million vehicle } \mathrm{km}\end{array}$ & 50 \\
\hline Beth and Pharoah ${ }^{21}$ & $\begin{array}{l}\text { Britain } \\
\text { London, Southall } \\
\text { London, Southall } \\
\text { Sheffield }\end{array}$ & $\begin{array}{l}\text { All accidents } \\
\text { Pedestrian accidents } \\
\text { Pedestrian accidents }\end{array}$ & $\begin{array}{l}49 \\
59 \\
50\end{array}$ \\
\hline
\end{tabular}

pavement. Children's freedom has been curtailed, ${ }^{5}$ and though the number of children killed and injured has decreased in Britain it is still very much higher than in many other countries, especially for the 10-14 years age group, as shown in table 3 . In order to reduce casualties, and to improve the quality of life, especially in inner city areas, residential streets should be freed from fast traffic. As Sharples $e t$ al say, 'Childhood mortality might be appreciably reduced if children at play were protected from traffic, particularly in socially deprived areas'. ${ }^{22}$

In Sweden all traffic is banned in some neighbourhoods. ${ }^{23}$ However this solution would not be popular in Britain as people fear that their cars would be stolen or broken into if they were not parked just outside the house.

In the Netherlands, Woonerven are very popular. ${ }^{24}$ Traffic is allowed access but physical means are used to reduce speed to about $5 \mathrm{mph}$. The road space is shared and there is provision for moving traffic, car parking, sitting out, and for children to play. To allow children to play on the street in safety the speed of traffic must be reduced to not much more than a walking pace. This requires traffic calming measures to be introduced at very frequent intervals which costs a lot of money. Thus the major disadvantage of Woonerven is their expense.

There is no reason to think that the low death rate for children in the Netherlands and Sweden is due to some difference in national character rather than physical safety measures. Similar reductions in accidents to children were accomplished in Salford in the 1930s. When 'play streets' were introduced, the number of children injured was nearly halved and the number killed was reduced from 11 in 1931 to one in $1936 .{ }^{25}$ When play streets were first introduced no vehicles were allowed on the streets; later this was changed to allow access only, but no through traffic. Play streets were effective but they cannot be recommended at present. The police say that they cannot enforce access-only orders.

\section{HOME ZONES}

Howarth et al have suggested these as a low cost measure to reduce casualties to young children in residential areas and allow them to play outdoors in safety. ${ }^{26-28}$ His proposal is that, within suitable small residential precincts, child pedestrians should have priority and any driver who injures a child should be presumed negligent; the principle of 'res ipsa loquitor'. The advantage would be that children could play outdoors in relative safety, but traffic would not be banned, so there should be no objections from fire or ambulance services. No extra police surveillance would be necessary. No speed limit is to be enforced; the offence would be to injure a child. The police would be involved, then as now, when an accident happened, but as there would be fewer accidents police time would be saved. Perhaps most important, homes zones would be very cheap to install, and so they would be suitable for inner city areas where the local authorities are short of money. 
Home zones would, however, require new legislation. This could be introduced nationally, or by some go ahead local authority. Within home zones, vehicles would have to travel very slowly, in order to stop in time if children were playing on the road. But, as each area would be very small, the distance travelled at this slow pace would only be a few hundred yards at most, the extra time required would be negligible. It has been suggested that if children got used to playing on the road in these areas they would also play on other roads and so accidents outside the protected home zones might increase. The boundaries of home zones must be clearly marked and children must be taught the difference between protected home zones and other roads. The possibility of accident migration must be considered seriously but the evidence, from Sweden, the Netherlands, and Salford, suggests that playing on the roads in residential safety zones does not lead to an overall increase in accidents.

Home zones are advocated here for their contribution to road safety. There would, however, be other advantages if they were introduced. They would improve the quality of life in deprived areas. It is, of course, quite impossible to show cause and effect, but improving this environment in inner city areas might be an important first step towards reducing violent crime (as usually defined) as well as preventing children from being injured by motor vehicles.

\section{The journey to and from school}

Children must attend school and so there is a special obligation to make the school journey as safe as possible. Many of the casualties incurred on the school journey occur near the schools. Traffic calming can be recommended for minor roads but on main roads, where speed restriction is only necessary when pupils are entering or leaving school, they might not be acceptable. On main roads speed limits may have to be enforced by police surveillance. In Britain, school crossing patrols are provided on some main roads near to primary schools; they see many children safely across busy roads. Nevertheless requests for a school crossing patrol are often refused. More should be employed, not only at school entrances but also on busy roads near to schools where many pupils cross. Most local authorities do not provide school crossing patrols for secondary school pupils. There should be either a school crossing patrol or a pelican crossing on the roads outside all schools. If pelican crossings are provided they should be wide enough to allow all the waiting children to cross the road while the 'steady green man' is showing and the lights are at red to stop the traffic. At a large secondary school 500 pupils may wish to cross the road in the 10 minutes after school closes. To allow the children to cross in safety the pelican crossing should have the maximum permitted width of 5 metres and an extended steady green man period when pupils are leaving school. Many secondary school pupils travel to school by bus and there is a mention of a bus in the reports of many of the accidents. ${ }^{29}$ Where it can possibly be arranged school buses should pull up by the school so that pupils can board or alight without having to cross the road.

\section{Summary of recommendations}

- Introduction of home zones in suitable residential areas.

- Introduction of special low speed limits on all roads outside schools, including secondary schools.

- Provision of more school crossing patrols near to primary schools.

- Provision of either pelican crossings or school crossing patrols on the roads outside secondary schools.

- Pelican crossings outside secondary schools must be adapted to deal with the large flow of pedestrians which may occur.

- There should be provision for all school buses to pull into special bus stops so that pupils may board and alight without having to cross the road.

- Traffic calming methods should be applied in all appropriate areas.

This review is an updated summary of the relevant parts of Cutting Pedestrian Casualties.

1 Office of Population Censuses and Surveys. Mortality statistics 1992, childhood, England and Wales. London: HMSO, 1993.

2 National Playing Field Association. Mean streets, the crisis on our doorsteps. London: National Playing Fields Associaour doorsteps.

3 Department of the Environment. Children at play. London: HMSO, 1973 .

4 Ward C. The child in the city. London: Bedford Square Press, 1990.

5 Hillman M, Adams J, Whitelegg J. One false move ... a study of children's independent mobility. London: Policy Studies Institute, 1990.

6 Department of Transport. Road accidents Great Britain 1987. London: HMSO, 1988.

7 Preston B. Statistical analysis of child pedestrian accidents. Accid Anal Prev 1972; 4: 323-32.

8 Lawson SD. Accidents to young pedestrians, Basingstoke: AA Foundation for Road Safety Research and Birmingham City Council, 1990

9 Preston B. Statistics of inequality. Sociol Rev 1974; 22: 103-18.

10 Preston B. Further statistics of inequality. Sociol Rev 1979; 27: $343-50$.

11 Office of Population Censuses and Surveys. Occupational mortality, decennial supplement, 1970-72. London HMSO, 1978 .

12 Office of Population Censuses and Surveys. Occupational mortality, childhood supplement, London: HMSO, 1988

3 Bradshaw $\mathbf{R}$. Why do parents drive their children to school? Traffic Engineering + Control 1995; 36: 16-9.

14 Preston B. Child pedestrian accidents in Manchester and Salford. Manchester: Manchester Polytechnic, 1976.

15 United Nations. Statistics of road traffic accidents in Europe. New York: United Nations, 1994.

16 Preston B. The impact of the motor car. Llanddewi Brefi: Brefi Press, 1991. (Available from Brefi press, Llanddewi Brefi. Tregaron, Dyfed SY25 6NY, Wales.)

17 Pharoah T, Russell J. Traffic calming: policy and evaluation in three European countries. Occasional paper 2/89. in three European countries. Occasional

18 Nielson OH, Rassin J. Environmental traffic management in Odense, Denmark. Built Environment 1986; 12(1/2): 83

19 Boyers PH. Environmental traffic restraint, approaches to traffic management by design. Built Environment 1986 12(1/2): $60-73$.

20 Whitelegg J. Environmental traffic management. In: Tolley $\mathrm{R}$, ed. The greening of urban transport. London: Bellhaven Press, 1990.

21 Beth L, Pharoah T. Adapting residental roads for safety and amenity. Occasional paper. London: South Bank Polytechnic, 1988.

22 Sharples PM, Story A, Aynsley-Green A. Eyre JA. Causes of fatal childhood accidents involving head injury in Northern region, 1979-86. BMF 1990; 301: 1193-7.

23 Thulin H. Safety in neighbourhoods in Sweden. Road safety: what next. Occasional paper 86/3. London: Policy safety: what next. Occas
Studies Institute, 1986.

24 Dutch Royal Touring Club. Woonerven. The Hague: Dutch Royal Touring Club, 1980. 
25 Godfrey CV. Roadsense for children. Oxford: Oxford University Press, 1937.

26 Howarth CI, Lightburn A. A strategic approach to child pedestrian safety. In: Foot HG, et al, eds. Road safety: research and practice, New York: Preager, 1981.

27 Howarth CI, Gunn MG. Pedestrian safety and the law. In: Chapman AJ, et al, eds. Pedestrian accidents. Chichester: Wiley, 1982.

28 Howarth CI. Streets safe for children? Walk. London:
Pedestrians Association, 1983; 13.

29 Preston B. Danger children crossing. New Scientist 1989 121: 73 (Feb).

30 Preston B. Cutting pedestrian casualties; cost-effective ways to make walking safer. A report from the Transport and Health Study Group. London: Transport and Health Study Group, 1992. (Available from Transport 2000, Walkden House, 10 Melton Street, London NW1 2EJ, UK.)

\section{Regular publications available}

Annual Report (National SAFE KIDS Campaign), Washington, DC, US

Australian Injury Prevention Bulletin, Bedford Park, South Australia

Building Bridges - Between Traffic Safety and Public Health (Education Development Center, Inc) Newton, MA, USA

Campaign Update, National SAFE KIDS Campaign, Washington, DC, US

Child Health (The Newsletter of the Canadian Institute of Child Health) Ottawa, ON, Canada

Childrens' Safety Network Notes, CSN, Newton, MA, US

Childhood Injury Control, Edmonton Board of Health

CHIRPP News (Canadian Hospitals Injury Reporting and Prevention Program, Health Canada), Ottawa, ON, Canada

Child Safety Review (The newsletter of the Child Accident Prevention Trust; (CAPT), London, England

Child Safety News (Child Safety Centre, Royal Children's Hospital) Parkville, Victoria, Australia

European Newsletter on Road Safety, European Road Safety Federation (ESRF) and the European Commission, The Hague, Netherlands

IPRC News, The University of North Carolina Injury Prevention Research Center, Chapel Hill, NC, US

La Lettre du CIRPAE, Paris, France

Safe Community News, Sundbyberg, Sweden

Safe Kids (Starship Children's Health), Auckland, NZ

Snapshots (Safe Kids Canada) Toronto, ON, Canada

Status Report, Insurance Institute for Highway Safety, Arlington, VA, US

\section{Occasional publications *}

Building Safe Communiities, State and Local Strategies for Preventing Injury and Violence, CSN and MCHB, Newton, MA, US

Childhood Injury: Cost and Prevention Facts, CSN Economics and Insurance Resource Center, National SAFE KIDS Campaign, Washington, US

Directory of Canadian Child/Youth Injury Prevention Programs and Researchers, Canadian Children's Safety Network, Toronto, ON, Canada

Drownings among 1 to 4 Year Old Children in Canada, Special Research Report, The Canadian Red Cross Society

Evaluation Guidebook for Community Youth Safety Programs, CSN and MCHB, Newton, MA, US

Motor Vehicle Injury Prevention: An assessment of Highway Safety and Public Health Activities in Selected States, National Highway Traffic Safety Administration, US

Publications Bibliography, Childrens Safety Network, National Injury and Violence Prevention Resource Center at EDC, Newton, MA,US

State MCH Injury Prevention Profiles, CSN and MCHB, Newton, MA, US

$\star$ For further details on obtaining any of these publications, please contact Barry Pless, Editor. Please submit any names of other such publications that have been omitted from this list. 